\title{
CONSTRAINS OF ONLINE EDUCATION IN INDIA
}

\author{
Dr Mohd Akhter Ali \\ Department of Geography \\ Osmania University, Hyderabad Telangana, India
}

\author{
M.Kamraju \\ Department of Geography \\ Osmania University, Hyderabad
}

\begin{abstract}
Online education is one of the significant transformation of education system throughout the globe. In the western Countries it evolved around the late 90's. But unfortunately in India it took $\mathbf{1 5}$ more years to lay its base. In online education the process of gaining knowledge becomes very easy. The main concept of online education is remote study: that is attaining knowledge without physical contact with the faculty or instructor. This method is very helpful to the students who are interested in learning but they can't afford to join regular academic institutions.

The main objective of this paper is to demarcate the constrains of Online education system in India. For the analysing of this paper we were mostly reliable on secondary data attained from various websites and feedbacks from parents and students. This paper will be useful for academician, researchers and entrepreneurs for developing better tool in progressive method of learning.
\end{abstract}

Keywords: education, transformation, knowledge, instructor, entrepreneurs

\section{INTRODUCTION}

Online learning is a type of instructive method which is delivered to the students via internet using their computers, mobiles, laptop, tablet, i-pad, etc. The simplest definition of online education is - 'gaining and attaining knowledge without physical contact with the faculty'. In India it has become a boon for learning various online courses in order to attain promotion and get better jobs.

Online educations are useful, and very helpful to those who don't have the resources (the capital, the time, or the right locality) to attend classes in the regular academic premises. However, I personally think that the face-to-face learning is far more efficient and effective way of learning.

The biggest constrain of online education is internet connectivity, wherever the student is the essential component is web connectivity if he has good network connectivity he can attend classes from anywhere on the globe without terrain restrictions. But unfortunately in India that is the major problem. Major share of the population are lacking in high quality internet connectivity.

But the momentum has drastically changed because of the COVID-19 lockdown. As this lockdown has huge impact on all the sectors but education sector is trying hard to revive it through online learning method. Teachers and faculties from school level to university level have started to take online classes, in platforms like Zoom, Meet, Skype, Duo, etc.

\section{OBJECTIVE}

The main objective of this paper is demarcate the constrains of online education system in India.

\section{METHODOLOGY}

We have used mostly secondary data for this research such as internet, newspapers, blogs, books, etc.

\section{LITERATURE REVIEW}

Anil K. DImri, \& Amit Chaturvedi (2009) In their paper they tried to critically analyze the crucial issues of students with reference to IGNOU by taking the perception of learners.

Avani Trivedi , \& Kalpana Gupte (2010) The article is mainly discusses about distance education and distance learning with particular reference to IGNOU.

Lalita Rajasingham (2011), The paper examines possible challenges of new educational the framework of open learning and e-learning environments.

Michael E. Ward, Gary Peters, Kyna Shelley (2010) This article explores the rationale for use of implementation of the technology, and the impact on learning.

Sharon L. Peterson, Louann Bierlein Palmer (2011), This study highlights the problem solving strategies used by students in a university.

\section{DISCUSSION}

Online education in India has come a long way with the development of technology. India is one of the nations that is developing at an exponential rate in terms of technology. With the population of more than 1.3 billion, the availability of high-speed internet and Smartphone's, India has the most number of technologically driven persons. The rise of the internet has changed the way of life in India. People like to do everything online, they shop online, do business online, make friends online, learn online etc. While e-Commerce being the most significant online industry, online education and learning stand right next to it. With the ever-increasing information 
available on the internet and the countless number of online courses many people in India prefer to learn online.

The first and for more step taken by the government during Lockdown was to close all the educational institutions in our country, which was obviously needed for our nation as probability of virus attack will be maximum in classrooms because of strength. In the mid March when the lockdown was extended most of the academic institutions decided to go for Online Classes. Some Institutions took help of YouTube, dedicated Apps and some created a new platform.

The Government has advised the teachers and academic institutions to continue communication with students through virtual lectures or portals like Massive Open Online Courses.

Eventually it could not be successful as the absence of physical classrooms and proper digital infrastructure, both teachers and students are facing unprecedented challenges.

The major challenge of Remote Learning is disparity in access-
1. Electricity
2. Internet Connection/ Internet Quality
3. Device: Smartphone's, Computer or Laptop.

I. Electricity: According to Government data (Saubhagya Scheme) $99 \%$ of Indian homes have electricity. But is the electricity 24 hours available? We all live in India so you will be knowing that we all have power cuts whether you are staying in urban area like Hyderabad or rural area like Mancherial or Tier III city like Guwahati.

According to Ministry of Rural Development, Data from the Mission Antyodaya, a nationwide survey of villages conducted by the ministry of rural development, found that $20 \%$ of the India's households received less than 8 hours of electricity. Only $47 \%$ received more than 12 hours.

The other option for this is UPS which works for half an hour, but unfortunately it may not be with everyone as most of our population is middle class people who rely on electricity for their household purpose.

II. According to Pew report 2019 only 24\% of Indian's have Smartphone's and the other remaining users are using feature phone in which videos cannot be played. Now one third of the Indian population has Smartphone's can the parents give that to their kids for classes. Is that phone extra or free? For Example: An auto driver has one Smartphone and he has two kids of different classes. How will he manage for his kid's online classes. Firslty will parents allow their kids to use phones for 4 to 5 hours? Very Few percentage of parents will allow their kids to use phones for 4 hours.

III. Now one more problem is Data. Generally the recharges in India are 1GB per day minimum. But unfortunately if the classes are for 2 to 3 hours then data will be exhausted very soon. Now can the people afford extra data pack/?
As because of Lockdown there is already no income generation so lower income groups will have data affordability problem as most of the population in India is Middle class and lower middle class.

Table 1: Percentage of Household with Computer and Internet Facility

\begin{tabular}{|l|l|l|l|}
\hline Indicator & \multicolumn{3}{|c|}{ Percentage } \\
\hline & Rural & Urban & $\begin{array}{l}\text { Rural + } \\
\text { Urban }\end{array}$ \\
\hline $\begin{array}{l}\text { Household Having } \\
\text { Computer }\end{array}$ & 4.4 & 23.4 & 10.7 \\
\hline $\begin{array}{l}\text { Household having } \\
\text { Internet facility }\end{array}$ & 14.9 & 42.0 & 23.8 \\
\hline \begin{tabular}{l} 
Source: NSO 2018 \\
\hline
\end{tabular} & & & \\
\hline
\end{tabular}

For this survey, a computer included devices like desktop computer, laptop computer, notebook, netbook, palmtop, tablet or similar handheld devices. However Smartphone's were not considered.

Table 2: Percentage of Household with Computer and Internet Facility for different states.

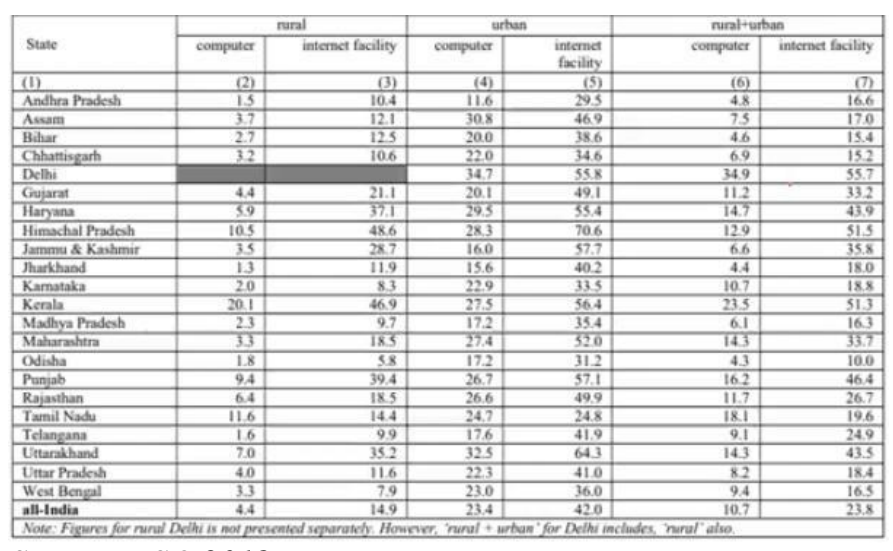

Source: NSO 2018

From this table it is seen that only few states have double digit figures such as Delhi, Kerala, Tamil Nadu, Haryana and Maharashtra and remaining have single digit figures which is very disparatative. 
Figure 1: Percentage of Persons of age 5 years and above who are able to operate computer, able to use internet

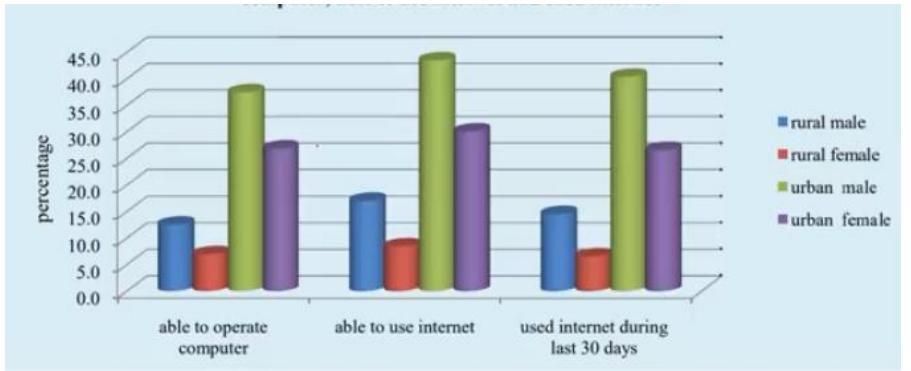

Source: NSO 2018

If we combine both the data only $8 \%$ of all the households with members aged between five and 24 have both a computer and an internet connection. So, out of 135 crore population only 5.29 crore population in have access to facilities. Here the situation changes if they have more than one kid.

The Digital Divide is evident across class, gender, religion or places of residence. Among the poorest 20\% household, only $2.7 \%$ have access to computer and $8.9 \%$ to Internet facilities. In case of the top $20 \%$ households, the proportions are $27.6 \%$ and $50.5 \%$. A peaceful Environment and a separate room to listen to online class is a luxury which many can't afford. That is why most of students opt hostels for peaceful study. But unfortunately now a day's hostels are becoming nuisance hubs.

According to Internet and Mobile Association of India report 2019 about $51 \%$ of internet penetration is there in urban area followed by $27 \%$ in rural area and $36 \%$ as All India Average.

The Gender Divide: In today's increasingly connected world where internet population is increasing every year, we still see clear gender divide. There are few female internet users in India as compared to males. There is high disparity between male and female internet users, which is more evident in rural. Given the penetration of internet users increasing rapidly with less female internet users in rural as compared to urban, there is huge potential for this segment to grow and reduce the gap in near future.

Among state groups, Kerala, Tamil Nadu and Delhi have a higher proportion of female internet users. The split of male and female is 60:40 in Metropolitan.

\section{Gender Distribution In Percentage}

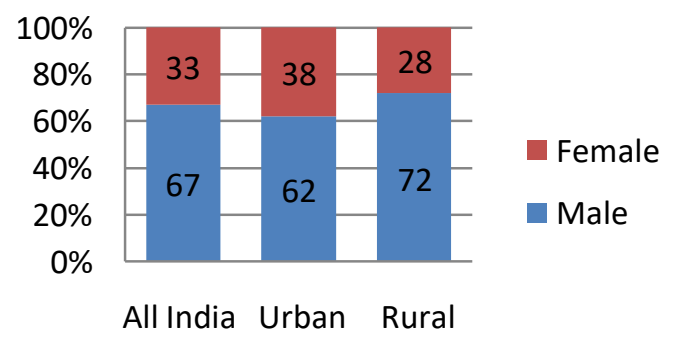

Source: Internet and Mobile Association of India report 2019

Poor Speed and Connectivity: Speed Test, a site that analyses internet access performance across the globe, in its latest report on tracking COVID-19's impact on speeds around the world which was updated on April 15, showed a $6 \%$ decline in fixed line speeds and $18 \%$ in mobile speeds when compared to the week of march $2^{\text {nd }}$. As per the report, India's current broadband speed is an average of 36.17 mbps and mobile download speed is $9.67 \mathrm{mbps}$. For online classes the internet should be continuously connected.

After lock down many parents are complaining about the increase in screen hours and because of it their children's are having headache, visibility problems.

Adapting to New Technology: Many teachers have never taught online $90 \%$ of the teachers are at learning stage. Many students have never learned online. A lot more discipline is required to learn online, as it has high amount of distractions such as social media, chatting, games, etc.

\section{CONCLUSION}

After COVID-19 lockdown most of the Educational Institutes are taking Classes on Google Meet, Zoom, Skype, Duo, etc. Faculties are trying really hard to take classes, but the main question is how many students are really attentive?

The hard work of faculties are somewhat going in vain only $2 \%$ of the students are attentive out of the $40 \%$ strength present.

So, With the existing digital divide, expanding online education will push the digital have- knots to the periphery of education system, thereby increasing inequality in educational outcomes.

If the government continues online education without necessary supportive measures, the prevailing disparity in 
the virtual world could translate into widening educational inequalities among learners.

\section{ACKNOWLEDGMENTS}

We are very Thankful to all the respondents who gave us their valuable view point on online education. We are also Thankful to P.Manisha, Sanja Devi, M Uma Maheshwari, K Ravali, G Kusumlatha, D. Raghu and O.Pranathi for their special feedback.

\section{REFERENCES}

1. Anil k.Dimri, Amit Chaturvedi (2010), Analysis with learner Input of students support services in India, Asian Journal of Distance Education, ISSN 1347-9008, vol.7,no 2 (2010).

2. Avani Trivadi and Kalpana Gupta (2010), Quality Issues for counselling in open and Distance Learning in India., Asian Journal of Distance Education,ISSN.13479008.Vol.8,no.2 (2010).

3. Durgesham, G., and M. Kamraju. "A Study on Educational Status and School Related Abilities in Model High School, Osmania University, Hyderabad."

4. Internet and Mobile Association of India report 2019

5. Kamraju, M., \& Kamraju, M. (2018). Changing Pattern of Urban Growth in Hyderabad City: A Study. Jai Maa Saraswati Gyanadayani, 3, 483-503.

6. Kamraju, M., M. Kamraju, and M. Vani. "Village Information System Using GIS: A Case Study of Chilkur Village, Moinabad Mandal Telangana." Jai Maa Saraswati Gyandayani 3: 21-31.

7. Kamraju, M., and Siva Prathaap. "HOW TO AVOID REJECTION OF RESEARCH PAPER BY JOURNALS." International Journal of Research and Analytical Reviews (IJRAR (2019).

8. Lalita Rajasingham (2011), New challenges facing universities in the Internet - driven global environment, European Journal of Open, Distance and E-learning, ISSN:1027- 5207, (2011).

9. Michael E. Ward, Gary Peters, Kyna Shelley (2010), Student and faculty perceptions of the quality of online learning experiences, The International review of research in Open and Distributed Learning (ISSN : 14923831), Vol 11, No. 3 (2010).

10. NSO Report 2018

11. Prathap, T. Siva, Mohd Akhter Ali, and M. Kamraju. "HOW TO WRITE AN ACADEMIC RESEARCH PAPER." (2019).

12. Sharon L. Peterson, Louann Bierlein Palmer (2011), Technology confidence, competence and problem solving strategies : Difference within face-to-face and online formats, Journal of Distance Education, (ISSN : 0830-0445), Vol 25, No 2 (2011). 